\title{
KARAKTERISTIK KOPI BUBUK ARABIKA (Coffea arabica L) TERFERMENTASI Saccharomyces cerevisiae
}

\author{
Mia Azizah ${ }^{1)^{*}}$, RTM Sutamihardja ${ }^{2)}$, Nova Wijaya ${ }^{2)}$ \\ ${ }^{1)}$ Progam Studi Biologi, FMIPA, Universitas Nusa Bangsa, Bogor \\ ${ }^{2)}$ Progam Studi Kimia, FMIPA, Universitas Nusa Bangsa, Bogor \\ Jl. K.H. Sholeh Iskandar KM. 4 Cimanggu Tanah Sereal, Bogor 16166 \\ *email: miaazizah23@ gmail.com
}

\section{ABSTRACT \\ Characteristics Of Arabica Ground Coffee (Coffea arabica L) Fermented by Saccharomyces cerevisiae}

\begin{abstract}
Coffee is one of the plantation commodities that have higher economic value among other plantation crops. Arabica coffee has superior quality and taste compared to others. Coffee has been widely processed into grounded coffee products. The quality of ground coffee is influenced by many factors; one of them is processing. In the processing of coffee fruit into coffee beans the process that is certain to occur is fermentation. Fermentation affects ground coffee quality products. This study focused on observing the quality of arabica ground coffee fermented by Saccharomyces cerevisiae. The quality parameters of the ground coffee observed include water content, coffee extract and caffeine content. Other qualities supporting parameters are $\mathrm{pH}$ of ground coffee and phytochemical test. In addition, the fermentation $\mathrm{pH}$ was also observed in the fermentation process, reducing sugar content and qualitative testing of ethanol. Saccharomyces cerevisiae concentration was varied $0 \%(K 0), 1 \%(K 1), 2 \%(K 2), 3 \%$ (K3) and 4\% (K4) with duration of fermentation is for 24 hours. The quality of arabica ground coffee products is in accordance with SNI Ground Coffee 01-3542-2004 with the following values: Water content 2,3-1,6\% b/b. Coffee extract 30,7-30,3\% b/b. Caffeine content 1,18-1,01\% b/b. The pH of brewed ground coffee is 6,5-5,1. Alkaloids, saponins and tannins were detected in all different treatments of ground coffee samples. Flavonoids were only detected in the treatment of $\mathrm{KO}$ ground coffee samples. The fermentation $\mathrm{pH}$ at the initial state was 5,61 and after fermentation was 4,91-3,89. Reducing sugar content at the initial state was 32,35\% b/b and after fermentation 21,2$4,3 \% \mathrm{~b} / \mathrm{b}$. Ethanol was detected in all samples before and after fermentation.
\end{abstract}

Keywords: Coffea Arabica L, Ground Coffee Quality, Fermentation, Saccharomyces cerevisiae

\begin{abstract}
ABSTRAK
Kopi merupakan salah satu komoditi perkebunan yang memiliki nilai ekonomis cukup tinggi diantara tanaman perkebunan lainnya. Kopi Arabika memiliki karakteristik dan cita rasa superior dibanding yang lainnya. Kopi banyak diolah menjadi produk kopi bubuk. Karakteristik kopi bubuk dipengaruhi oleh banyak faktor, diantaranya adalah cara pengolahan. Pengolahan dari buah kopi menjadi biji kopi salah satu proses yang pasti dilalui, yaitu fermentasi. Penelitian ini difokuskan pada karakterisasi kopi bubuk Arabika hasil fermentasi menggunakan Saccharomyces cerevisiae. Parameter yang diamati meliputi kadar air, sari kopi dan kadar kafein. Parameter penunjang lainnya, yaitu $\mathrm{pH}$ seduhan kopi bubuk dan uji fitokimia. Selain itu, selama proses fermentasi diamati $\mathrm{pH}$ fermentasi, kadar gula pereduksi dan uji kualitatif etanol. Konsentrasi S. cerevisiae divariasikan $0 \%(\mathrm{~K} 0), 1 \%(\mathrm{~K} 1), 2 \%(\mathrm{~K} 2), 3 \%(\mathrm{~K} 3)$ dan 4\% (K4) dengan waktu fermentasi selama 24 jam. Karakteristik kopi bubuk Arabika yang dihasilkan sesuai dengan SNI Kopi Bubuk Nomor 01-3542-2004 yaitu kadar air 2,33-1,6\% b/b, sari kopi 30,7 - 30,3\% b/b, kadar kafein 1,18$1,01 \% \mathrm{~b} / \mathrm{b}$ dan $\mathrm{pH}$ seduhan kopi bubuk 6,5-5,1. Alkaloid, saponin dan tanin terdeteksi pada semua perlakuan sampel kopi bubuk. Flavonoid hanya terdeteksi pada perlakuan sampel kopi bubuk K0. pH fermentasi pada keadaan awal 5,61 dan setelah fermentasi 4,91-3,89. Kadar gula pereduksi pada keadaan awal 32,35\% b/b dan setelah fermentasi $21,2-4,3 \%$ b/b. Etanol terdeteksi pada semua sampel sebelum dan setelah fermentasi.
\end{abstract}

Kata kunci: Coffea Arabica L, mutu kopi bubuk, Fermentasi, Saccharomyces cerevisiae

\section{PENDAHULUAN}

Kopi merupakan salah satu hasil komoditi perkebunan yang memiliki nilai ekonomis cukup tinggi di antara tanaman perkebunan lainnya (Yusdiali, 2008). Kopi terdiri dari banyak jenis antara lain yang sering dijumpai, yaitu kopi Arabika (Coffea arabica) dan kopi robusta (Coffea canephora). Kopi Arabika memiliki karakteristik dan cita rasa yang lebih superior dibandingkan dengan kopi robusta (Najiyati 
dan Danarti, 2001). Kopi banyak digunakan sebagai minuman penyegar karena memiliki cita rasa yang khas, sehingga digemari oleh berbagai lapisan masyarakat di seluruh dunia. Minuman kopi dibuat dari seduhan produk olahan kopi yang sering dijumpai contohnya kopi bubuk (Bina UKM, 2011). Karakteristik kopi bubuk dipengaruhi oleh banyak faktor salah satunya cara pengolahan. Pengolahan buah kopi menjadi biji kopi dapat dilakukan dengan berbagai cara, namun ada satu tahapan yang sama-sama dilalui yaitu proses fermentasi (Hoffmann, 2014).

Fermentasi kopi bertujuan untuk melepaskan lapisan lendir (mucilage) yang masih melekat pada biji (Panggabean, 2011). Dekomposisi lapisan lendir (mucilage) selama fermentasi biji kopi terjadi karena adanya aktivitas metabolisme mikroorganisme yang berasal dari lingkungannya (Frank et al., 1996). Mucilage kaya akan pektin dan gula (Murthy dan Naidu, 2011). Mucilage menjadi sumber nutrisi mikroorganisme selama proses fermentasi (Board, 1983). Saccharomyces cerevisiae merupakan salah satu kelompok mikroorganisme yang banyak diteliti berkaitan dengan kemampuannya memfermentasi gula (Gadd, 1998).

Sebelumnya telah dilakukan penelitian fermentasi kopi robusta menggunakan koji $S$. cerevisiae var. ellipsoideus dengan variasi konsentrasi $0 \%, 1 \%, 2 \%, 3 \%$ dan $4 \%$ dengan waktu fermentasi 24 jam, menunjukkan bahwa konsentrasi kopi semakin tinggi berpengaruh nyata pada penurunan kadar air, kadar asam, dan kadar kafein kopi bubuk (Ikrawan et al., 2012). Avallone (2002) melakukan penelitian tentang fermentasi kopi secara alami dengan durasi waktu fermentasi 20 jam, menyatakan bahwa pada proses fermentasi terjadi penurunan $\mathrm{pH}$ dan kadar gula pereduksi, serta terbentuknya etanol. Berdasarkan hal tersebut, maka dilakukan penelitian untuk menganalisis karakteristik kopi bubuk Arabika terfermentasi $S$. cerevisiae dan analisis $\mathrm{pH}$ fermentasi, kadar gula pereduksi, serta uji kualitatif etanol dari proses fermentasi. Pada penelitian ini dilakukan variasi konsentrasi $S$. cerevisiae $0 \%, 1 \%, 2 \%, 3 \%$ dan $4 \%$ dengan durasi waktu fermentasi 24 jam.

\section{BAHAN DAN METODE}

\section{Bahan dan Alat}

Bahan yang digunakan yaitu buah kopi Arabika matang berwarna merah yang berasal dari daerah Cipanas, Bogor, standar kafein, $S$. cerevisiae (ragi fermipan), amonia $\left(\mathrm{NH}_{4} \mathrm{OH}\right)$ pekat, etanol, kalsium karbonat $\left(\mathrm{CaCO}_{3}\right)$, larutan $\mathrm{KI} 20 \%$, larutan $\mathrm{FeCl}_{3} 5 \%$, kloroform $\left(\mathrm{CHCl}_{3}\right)$, larutan natrium tiosulfat $0,1 \mathrm{~N}$, larutan $\left(\mathrm{NH}_{4}\right)_{2} \mathrm{HPO}_{4} \quad 10 \%$, pereaksi Dragendorff, pereaksi Luff Schoorl, pereaksi Mayer, pereaksi Wagner.

Alat yang digunakan yaitu ayakan 60 mesh, blender, botol plastik ukuran $1500 \mathrm{~mL}$ beserta tutup, selang, buret $50 \mathrm{~mL}$, cawan porselen, corong, corong pisah, desikator, oven, hotplate, kertas saring, labu distilasi, pemanas listrik, pendingin tegak, $\mathrm{pH}$ meter, neraca analitik, oven, spektrofotometer UVVis Optizen, water bath, dan peralatan gelas lainnya.

\section{Metode}

Tahapan metode penelitian antara lain fermentasi kopi, analisis proses fermentasi, pembuatan kopi bubuk, uji fitokimia, derajat keasaman ( $\mathrm{pH}$ seduhan kopi bubuk), dan analisis karakteristik kopi bubuk.

\section{A. Fermentasi kopi (Ikrawan et al., 2012)}

Fermentasi kopi Arabika dilakukan dengan fermentasi basah yaitu dengan penambahan bakteri $S$. cerevisiae dengan variasi konsentrasi, yaitu $0 \%, 1 \%, 2 \%, 3 \%$, $4 \%$ dari bobot gabah basah.

\section{B. Analisis Proses Fermentasi \\ 1. pH Fermentasi (Rahim, 2009)}

$\mathrm{pH}$ diukur dengan menggunakan $\mathrm{pH}$ meter terhadap sampel sebelum dan setelah fermentasi.

\section{Kadar Gula Pereduksi (Metode Luff Schoorl (SNI 3547.2-2008))}

Penentuan kadar gula pereduksi dilakukan dengan metode Luff Schoorl. Prinsip dari metode ini yaitu reduksi $\mathrm{Cu}^{2+}$ menjadi $\mathrm{Cu}^{+}$oleh monosakarida bebas. Kelebihan $\mathrm{Cu}^{2+}$ ( yang tidak direduksi) diukur dengan titrasi iodometri. 


\section{Uji Kualitatif Etanol (Ahuja dan Jespersen, 2006)}

Uji kualitatif etanol dilakukan melalui identifikasi warna. Adanya etanol ditandai dengan terbentuknya warna merah dengan pemberian larutan serium (IV) amonium nitrat dan aquades pada destilat cairan fermentasi.

\section{Pembuatan Kopi Bubuk}

Biji kopi hasil fermentasi dicuci dengan air mengalir kemudian dikeringkan dengan oven pada suhu $60^{\circ} \mathrm{C}$ selama 25 jam. Biji kopi dikupas kulit tanduk dengan huller sehingga diperoleh kopi beras. Kopi beras disangrai dengan oven pada suhu $190^{\circ} \mathrm{C}$ selama 20 menit. Sampel digiling dengan blender hingga menjadi kopi bubuk. Kopi bubuk disaring dengan penyaring ukuran 60 mesh.

\section{Uji Fitokimia (Harborne, 1987)}

Uji Fitokimia dilakukan berdasarkan pembentukan warna/endapan dengan pereaksi uji. Uji alkaloid menggunakan pereaksi Wagner, Mayer, dan Dragendorrf. Hasil positif ditandai dengan terbentuknya endapan berwarna coklat (Wagner), putih atau kuning (Mayer), merah kecoklatan (Dragendorff). Uji flavonoid dengan melihat terbentuknya kompleks berwarna ungu dengan $\mathrm{Mg}$ ditambah $\mathrm{HCl}$ pekat. Keberadaan saponin dilihat dari pembentukan busa yang stabil setelah penambahan akuades dan pengocokan. Uji tanin dilakukan dengan pereaksi $\mathrm{FeCl}_{3}$ dan pembentukan warna hijau, biru tua, atau hitam kehijauan menandakan keberadaan tanin.

\section{E. Derajat Keasaman}

$\mathrm{pH}$ seduhan kopi diukur dengan menggunakan $\mathrm{pH}$ meter.

\section{F. Analisis Karakteristik Kopi Bubuk \\ 1. Kadar Air (SNI 01-2891-1992)}

Sampel kopi bubuk ditimbang sebanyak 1-2 g pada cawan porselen yang telah dikeringkan dan diketahui bobot kosongnya. Sampel dimasukkan ke dalam oven selama 3 jam dengan suhu $105^{\circ} \mathrm{C}$. Sampel disimpan di dalam desikator selama 15 menit dan ditimbang kembali untuk mengetahui bobot setelah pemanasan. Kadar air dihitung menggunakan rumus sebagai berikut:

$$
\text { Kadar Air }(\% \mathrm{~b} / \mathrm{b})=\frac{W_{1}}{\mathrm{~W}} \times 100 \%
$$

Keterangan:

$\mathrm{W}$ : Bobot sampel sebelum dikeringkan

$\mathrm{W}_{1}$ : Kehilangan bobot setelah dikeringkan

\section{Sari Kopi (SNI 01-3542-2004)}

Sampel kopi bubuk ditimbang sebanyak $2 \mathrm{~g}$ dan dimasukkan ke dalam gelas piala 500 $\mathrm{mL}$. Air mendidih $\left(95^{\circ} \mathrm{C}\right)$ ditambahkan sebanyak $200 \mathrm{~mL}$ dan didiamkan selama 1 jam. Larutan sampel disaring ke dalam labu ukur $500 \mathrm{~mL}$, dibilas dengan air panas sampai larutan menjadi jernih. Larutan dibiarkan sampai suhu kamar, air ditambahkan hingga tepat pada tanda tera (garis batas). Larutan dipipet $50 \mathrm{~mL}$ ke dalam pinggan porselin yang telah diketahui bobotnya. Larutan dipanaskan di atas penangas air sampai mengering sehingga diperoleh ekstrak kering kopi. Ekstrak kering dimasukkan ke dalam oven dengan suhu $105 \pm 2^{\circ} \mathrm{C}$ selama 2 jam. Sampel didinginkan di desikator selama 15 menit dan ditimbang hingga bobot konstan. Sari kopi dihitung dengan rumus:

$$
\text { Sari Kopi }(\% \mathrm{~b} / \mathrm{b})=\frac{\mathrm{W}_{1} \times 500}{\mathrm{~W}_{2} \times 50} \times 100 \%
$$

Keterangan:

$\mathrm{W}_{1} \quad$ : Bobot ekstrak (gram)

$\mathrm{W}_{2}$ : Bobot sampel (gram)

$500 \mathrm{~mL}$ : Volume pengenceran sampel (ml) $50 \mathrm{~mL}$ : Volume pengambilan sampel (ml)

\section{Kadar Kafein (Fitri, 2009)}

\section{a. Pembuatan Larutan Standar Kafein}

Standar kafein sebanyak $100 \mathrm{mg}$ dimasukkan ke dalam labu ukur $1000 \mathrm{~mL}$ dan ditepatkan hingga tanda batas dengan akuades $(100 \mathrm{mg} / \mathrm{L})$. Larutan standar tersebut kemudian dipipet sebanyak $0 ; 0,25 ; 0,5 ; 1 ; 2$; $3 ; 4 ; 5 ; 7,5 ; 10 \mathrm{~mL}$ ke dalam labu takar 50 $\mathrm{mL}$ dan ditepatkan hingga tanda batas dengan akuades untuk mendapatkan konsentrasi larutan standar sebesar $0 ; 0,5 ; 1 ; 2 ; 4 ; 6 ; 8$; 10; 15; dan $20 \mathrm{mg} / \mathrm{L}$. Larutan standar tersebut diukur dengan spektrofotometer pada panjang gelombang maksimum $(250-300 \mathrm{~nm})$, dan kemudian dibuat kurva kalibrasi hubungan antara absorbansi dengan konsentrasi larutan standar. 


\section{b. Penentuan Panjang Gelombang Maksimum Kafein}

Larutan standar kafein sebanyak $4 \mathrm{~mL}$ dengan konsentrasi 100 ppm dipipet, dimasukkan ke dalam labu ukur $50 \mathrm{~mL}$, diencerkan dengan akuades hingga garis tanda dan dihomogenkan. Larutan standar yang diukur absorbansinya dengan spektrofotometer UV pada panjang gelombang 250-300 nm. Sebagai uji blanko digunakan akuades.

\section{c. Ekstraksi dan Pengukuran Kadar Kafein}

Sampel kopi bubuk sebanyak 1 g dimasukkan ke dalam gelas piala, ditambahkan $150 \mathrm{~mL}$ air panas dan diaduk selama 2 menit. Larutan kopi disaring melalui corong dengan kertas saring ke dalam erlenmeyer. Serbuk $\mathrm{CaCO}_{3}$ sebanyak 1,5 gram dan larutan kopi dan dimasukkan ke dalam corong pisah lalu diekstraksi sebanyak 4 kali, masing-masing dengan penambahan $25 \mathrm{~mL}$ kloroform. Lapisan bawah (fraksi kloforom) diambil, diuapkan dengan water bath hingga membentuk ekstrak kering. Ekstrak kering tersebut dimasukkan ke dalam labu ukur $100 \mathrm{~mL}$ dan diencerkan dengan akuades hingga $100 \mathrm{~mL}$. Larutan sampel diukur absorbansi pada panjang gelombang maksimum (250-300 nm). Perhitungan kadar kafein pada kopi bubuk adalah sebagai berikut:

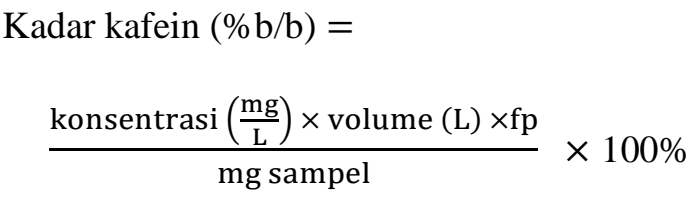

\section{HASIL DAN PEMBAHASAN}

\section{A. Analisis Proses Fermentasi \\ 1. pH Fermentasi}

Hasil pengamatan terlihat bahwa semakin tinggi penambahan konsentrasi Saccharomyces cerevisiae maka $\mathrm{pH}$ fermentasi akan semakin menurun. Berikut ini adalah hasil $\mathrm{pH}$ fermentasi pada Tabel 1.
Tabel 1.pH Fermentasi

\begin{tabular}{ccc}
\hline No. & Sampel & pH Fermentasi \\
\hline 1. & K0 (i) & 5,61 \\
2. & K0 (f) & 4,91 \\
3. & K1 & 4,30 \\
4. & K2 & 4,16 \\
5. & K3 & 4,10 \\
6. & K4 & 3,89 \\
\hline
\end{tabular}

Keterangan:

K0(i) : Sebelum Fermentasi

K0(f) : Konsentrasi S. cerevisiae 0\%

K1 : Konsentrasi S. cerevisiae $1 \%$

K2 : Konsentrasi S. cerevisiae 2\%

K3 : Konsentrasi S. cerevisiae 3\%

K4 : Konsentrasi S. cerevisiae 4\%

Selama fermentasi gula pereduksi dan pektin yang terdapat pada mucilage didegradasi oleh $S$. cerevisiae melalui serangkaian reaksi enzimatis menjadi etanol yang bersifat asam dan asam organik lainya. $S$. cerevisiae menghasilkan enzim zimase yang mengubah glukosa menjadi etanol, dan enzim pektinolitik yang mengubah pektin menjadi asam organik seperti asam pektinat, asam pektat serta asam galakturonat. Selama metabolisme glukosa berlangsung asam organik lainnya dihasilkan antara lain asam piruvat, asam asetat, asam sitrat, asam malat dan asam suksinat. Semakin banyak $S$. cerevisiae yang ditambahkan pada fermentasi maka produksi enzim akan semakin banyak sehingga semakin banyak komponen dalam biji kopi yang diuraikan (Ikrawan et al., 2012). Hal inilah yang menyebabkan penurunan $\mathrm{pH}$ pada sampel dengan penambahan $S$. cerevisiae

\section{Kadar Gula Pereduksi}

Murthy (2011) menyatakan perubahan penting dan nyata terjadi selama fermentasi kopi adalah degradasi lapisan lendir yang mengelilingi permukaan biji yang disebut dengan mucilage. Mucilage terdiri dari senyawa pektin, gula pereduksi, gula non pereduksi, selulosa dan mineral. Berikut ini adalah hasil kadar gula pereduksi pada lapisan lendir (mucilage) kopi (Tabel 2). 
Tabel 2. Kadar Gula Pereduksi

\begin{tabular}{ccc}
\hline No. & Sampel & $\begin{array}{c}\text { Kadar Gula Pereduksi (\% } \\
\text { b/b) }\end{array}$ \\
\hline 1. & K0 (i) & 32,35 \\
2. & K0 (f) & 21,28 \\
3. & K1 & 4,99 \\
4. & K2 & 4,68 \\
5. & K3 & 4,53 \\
6. & K4 & 4,38 \\
\hline
\end{tabular}

Hasil pengamatan menunjukan bahwa pada keadaan awal sampel mucilage memiliki kadar gula pereduksi yang tinggi. Hal ini sesuai dengan pernyataan Avallone et al (2002) yang menyatakan bahwa mucilage terdiri dari senyawa gula pereduksi yaitu glukosa dan fruktosa sebanyak $30 \%$. Sampel dengan penambahan konsentrasi $S$. cerevisiae yang semakin tinggi menunjukkan penurunan yang tidak berbeda terhadap kadar gula pereduksi. Kadar gula reduksi yang tinggi menunjukkan bahwa jumlah molekul fruktosa yang masih dalam bentuk oligofruktosa menjadi lebih sedikit, karena sebagian besar telah dihidrolisis menjadi monomernya (Tejasari et al., 2010).

\section{Uji Kualitatif Etanol}

Pembentukan etanol terjadi melalui jalur Embden-Meyerhorf-Parnas (EMP). Pada jalur EMP, glukosa dipecah menjadi 2 molekul asam piruvat melalui jalur glikolisis, kemudian piruvat terdekarboksilasi menjadi asetaldehida dan $\mathrm{CO}_{2}$ lalu diubah menjadi etanol oleh enzim alkohol dehidrogenase (Daud et al., 2010). Berikut ini adalah hasil uji kualitatif etanol cairan fermentasi pada Tabel 3.

\begin{tabular}{ccc}
\multicolumn{3}{c}{ Tabel 3. Uji Kualitatif Etanol } \\
\hline No. & Sampel & Pengamatan \\
\hline 1. & K0 (i) & + \\
2. & K0 (f) & + \\
3. & K1 & ++ \\
4. & K2 & ++ \\
5. & K3 & +++ \\
6. & K4 & +++ \\
\hline
\end{tabular}

Keterangan:

$+\quad$ : Kurang Pekat

$+\quad$ : Pekat

$++\quad$ : Sangat Pekat

Hasil pengamatan mengindikasikan bahwa semua sampel terdeteksi mengandung etanol. Uji kualitatif etanol dilakukan dengan larutan serium (IV) amonium nitrat yang merupakan agen pengoksidasi yang akan bereaksi dengan alkohol membentuk larutan kompleks berwarna merah.

\section{B. Uji Fitokimia}

Menurut Gunalan et al (2012) komponen kimia pada kopi Arabika adalah tanin, alkaloid, flavonoid, koumarin, kuinon, fenol dan minyak atsiri. Dari hasil pengamatan diperoleh bahwa sampel kopi bubuk Arabika terdeteksi mengandung alkaloid, saponin, dan tanin. Berikut ini adalah hasil uji fitokimia kopi bubuk Arabika (Tabel 4).

Tabel 4. Hasil Fitokimia Kopi Bubuk Arabika

\begin{tabular}{cclllllll}
\hline \multirow{2}{*}{ No. } & \multirow{2}{*}{ Sampel } & \multicolumn{7}{c}{ Parameter } \\
\cline { 3 - 6 } & & Wagner & Mayer & Dragendorff & & \multirow{2}{*}{ Flavonoid } & Saponin & \multirow{2}{*}{ Tanin } \\
\cline { 3 - 7 } & K0 & +++ & +++ & + & ++ & ++ & +++ \\
2 & K1 & ++ & ++ & - & - & ++ & ++ \\
3 & K2 & ++ & ++ & - & - & ++ & ++ \\
4 & K3 & ++ & ++ & - & - & ++ & +++ \\
5 & K4 & +++ & +++ & - & - & ++ & +++ \\
\hline
\end{tabular}

Keterangan:

- : Tidak Terdeteksi

$+\quad$ : Kurang Pekat

$+\quad$ :Pekat

$++\quad$ : Sangat Pekat 
Hasil pengujian alkaloid pada kopi bubuk Arabika diperoleh hasil terdeteksi. Sampel dinyatakan positif mengandung alkaloid apabila paling tidak menghasilkan dua uji positif dari tiga pereaksi yang digunakan. Kafein merupakan senyawa alkaloid yang terdapat dalam kopi. Kandungan kafein pada kopi Arabika yaitu $1,61 \mathrm{~g} / 100 \mathrm{~g}$ (Ling et al., 2000). Hasil uji fitokimia menunjukkan bahwa semakin tinggi penambahan konsentrasi $S$. cerevisiae maka alkaloid dalam sampel mengalami penurunan. Hal ini disebabkan karena selama proses fermentasi lapisan lendir (mucilage) yang telah hilang akan memudahkan enzim proteolitik dari Saccharomyces cerevisiae untuk masuk ke dalam sitoplasma dan menguraikan kafein pada biji kopi (Ridwansyah, 2003).

Saponin yang terdapat dalam kopi, yaitu kafestol dan kahweol (Farah, 2012). Timbulnya busa menunjukkan adanya glikosida yang yang terhidrolisis menjadi glukosa dan senyawa lainnya yang mampu membentuk buih (Rusdi, 1990). Saponin merupakan senyawa aktif permukaan yang bersifat sama seperti sabun sehingga dapat menimbulkan buih. Saponin dalam tanaman berkerja sebagai anti mikroba yang dapat menghambat pertumbuhan baik bakteri maupun jamur (Robinson, 1995).

Sampel kopi bubuk Arabika hasil fermentasi yang digunakan terdeteksi mengandung tanin. Asam klorogenat merupakan senyawa golongan tanin yang terkandung dalam kopi Arabika dengan jumlah sekitar 5,5-8,0\% (Clarke dan Macrae, 1987). Asam klorogenat merupakan salah satu komponen yang memberikan kontribusi terhadap sifat keasaman pada minuman kopi. Hasil uji fitokimia menunjukkan bahwa semakin tinggi penambahan konsentrasi $S$. cerevisiae maka tanin dalam sampel mengalami penurunan. Menurut Ikrawan et al (2012) kadar asam klorogenat menurun seiring dengan penurunan kadar kafein.

\section{Derajat Keasaman (pH Seduhan Kopi Bubuk)}

Salah satu faktor penting yang mempengaruhi $\mathrm{pH}$ seduhan kopi bubuk adalah proses fermentasi biji kopi. Berikut ini adalah hasil $\mathrm{pH}$ seduhan kopi bubuk pada Tabel 5.

Tabel 5. pH Seduhan Kopi Bubuk

\begin{tabular}{ccc}
\hline No. & Sampel & $\mathrm{pH}$ \\
\hline 1. & $\mathrm{~K} 0$ & 6,58 \\
2. & $\mathrm{~K} 1$ & 5,67 \\
3. & $\mathrm{~K} 2$ & 5,49 \\
4. & $\mathrm{~K} 3$ & 5,20 \\
5. & K4 & 5,10 \\
\hline
\end{tabular}

Fermentasi pada mucilage oleh Saccharomyces cerevisiae menghasilkan etanol yang bersifat asam dan asam organik lainya seperti asam pektinat, asam pektat serta, galakturonat, asam piruvat, asam asetat, asam sitrat, asam malat dan asam suksinat. Semakin banyak $S$. cerevisiae yang ditambahkan pada fermentasi maka produksi enzim akan semakin banyak sehingga semakin banyak komponen dalam biji kopi yang diuraikan (Ikrawan et al., 2012).

$\mathrm{pH}$ seduhan kopi bubuk Arabika mengalami penurunan seiring dengan meningkatnya konsentrasi penambahan S.cerevisiae. Penurunan nilai $\mathrm{pH}$ seduhan kopi Arabika disebabkan karena asam-asam organik yang terbentuk selama fermentasi kopi masih tersisa (Butt et al., 2011).

\section{Analisis Karakteristik Kopi Bubuk \\ 1. Kadar Air}

Kadar air mempengaruhi daya tahan bahan selama penyimpanan terhadap serangan mikroorganisme (Winarno, 1992). Kopi bubuk diharapkan mempunyai kadar air yang rendah karena dapat meningkatkan ketahanan kopi bubuk dari kerusakan akibat mikroorganisme selama penyimpanan (Pastiniasih, 2012). Berikut ini adalah hasil pengujian kadar air kopi bubuk pada Tabel 6 .

Tabel 6. Kadar Air

\begin{tabular}{ccc}
\hline No. & Sampel & Kadar Air $(\% \mathrm{~b} / \mathrm{b})$ \\
\hline 1. & K0 & 2,33 \\
2. & K1 & 2,20 \\
3. & K2 & 2,00 \\
4. & K3 & 1,96 \\
5. & K4 & 1,68 \\
\hline
\end{tabular}


Kadar air pada semua sampel kopi bubuk Arabika hasil fermentasi memenuhi persyaratan SNI Kopi Bubuk 01-3542-2004 dengan batas maksimum 7\%. Sampel dengan penambahan konsentrasi $S$. cerevisiae $4 \%$ (K4) memiliki kadar air yang terbaik karena pada perlakuan tersebut menghasilkan nilai kadar air paling rendah. Kadar air kopi bubuk Arabika hasil fermentasi cenderung nilainya menurun. Hasil ini sesuai dengan pernyataan Sivetz dan Foote (1963) yang menyatakan bahwa kadar air kopi bubuk akan semakin rendah ketika konsentrasi Saccharomyces cerevisiae semakin tinggi karena jumlah air bebas yang terdapat pada lendir kopi semakin banyak digunakan oleh mikroorganisme untuk berkembang biak.

\section{Sari Kopi}

Sari kopi menunjukkan jumlah zat yang terlarut dalam air selama penyeduhan (Nopitasari, 2010). Sari kopi yang diperoleh berdasarkan variasi penambahan konsentrasi $S$. cerevisiae menunjukkan hasil yang tidak berbeda jauh antar satu dengan yang lainnya. Berikut ini adalah hasil pengujian kadar sari kopi bubuk pada Tabel 7.

\begin{tabular}{|c|c|c|}
\hline No. & Sampel & Sari Kopi $(\%$ b/b) \\
\hline 1. & K0 & 30,51 \\
\hline 2. & K1 & 30,66 \\
\hline 3. & $\mathrm{~K} 2$ & 30,41 \\
\hline 4. & K3 & 30,74 \\
\hline 5. & $\mathrm{~K} 4$ & 30,35 \\
\hline
\end{tabular}

Sari kopi pada semua sampel kopi bubuk Arabika hasil fermentasi memenuhi persyaratan SNI Kopi Bubuk 01-3542-2004 dengan rentang yaitu 20-36\%. Hasil ini sesuai dengan pernyataan Maria (2009) bahwa konsentrasi $S$. cerevisiae tidak berpengaruh terhadap sari kopi bubuk. Sari kopi berhubungan dengan kelarutannya. Faktor-faktor yang mempengaruhi kelarutan, yaitu suhu, waktu dan luas permukaan. Menurut Ramadhan dan Phaza (2010) seiring dengan naiknya suhu ekstrasi maka laju ekstraksi akan meningkat. Selain itu, waktu kontak sampel dengan pelarut yang semakin lama akan meningkatkan kelarutan material yang terekstrak. Menurut Yeretzian et al (2012) sari kopi dipengaruhi oleh ukuran partikel dan luas permukaan. Kopi bubuk Arabika disaring dengan ukuran 60 mesh sehingga memiliki kadar sari yang tidak berbeda jauh karena memiliki ukuran partikel yang sama.

\section{Kadar Kafein}

Kadar kafein diukur menggunakan metode spektrofotometri dikarenakan penggunaan metode spektrofotometri UV-Vis lebih efisien dalam segi biaya dan waktu dibanding dengan penggunaan metode KCKT (Sabrina, 2012). Panjang gelombang maksimum adalah panjang gelombang yang memiliki nilai absorbansi tertinggi. Dari hasil pengamatan terlihat bahwa kafein terdeteksi pada daerah UV yaitu pada panjang gelombang $275 \mathrm{~nm}$ (Gambar 1). Hasil pengamatan terlihat bahwa kafein terdeteksi pada daerah UV yaitu pada panjang gelombang $275 \mathrm{~nm}$. Panjang gelombang maksimum yang diperoleh dari deret standar kafein selanjutnya akan digunakan untuk pengukuran kadar kafein. Deret standar kafein kemudian dibuat kurva standar kafein. Kurva tersebut merupakan hubungan antara konsentrasi (sumbu x) dengan absorbansi (sumbu y) sehingga diperoleh persamaan garis yang selanjutnya akan digunakan untuk perhitungan kadar kafein kopi bubuk.

Standar kafein menghasilkan persamaan regresi $\mathrm{y}=0,0498 \mathrm{x}-0,0017$ dengan koefisien korelasi sebesar 0,9979. Hasil koefisien korelasi yang didapat dinyatakan baik untuk standar kafein, karena nilai koefisien korelasi yang diperoleh berada di atas batas minimum menurut Association of Official Analytical Chemist (AOAC, 2005) yaitu > 0,9900 (Gambar 2). 


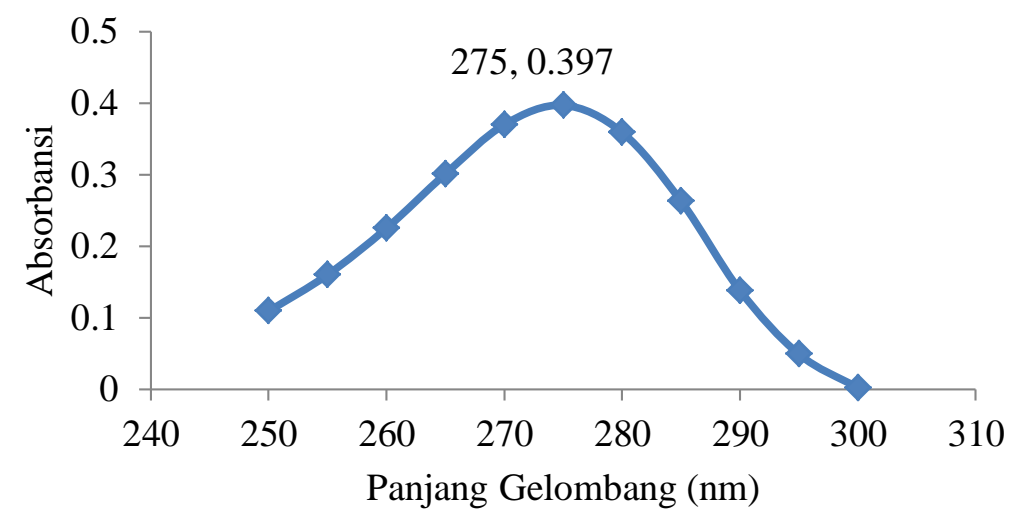

Gambar 1. Panjang Gelombang Maksimum Kafein

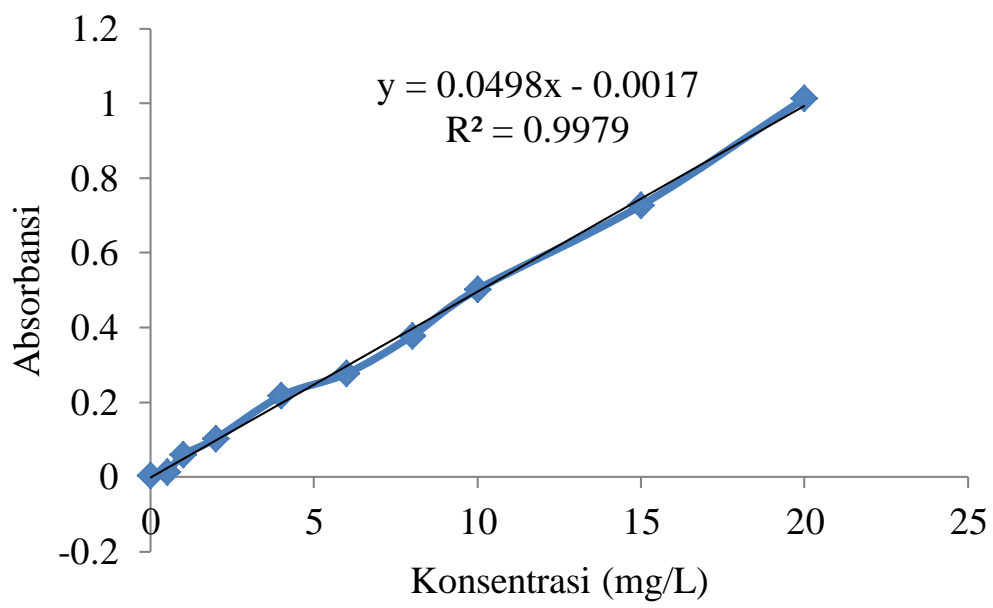

Gambar 2. Kurva Standar Kafein

Berikut ini kadar kafein kopi bubuk Arabika yang diperoleh dari pengukuran absorbansinya pada panjang gelombang 275 nm (Tabel 8).

Tabel 8. Kadar Kafein

\begin{tabular}{ccc}
\hline No. & Sampel & Kadar Kafein $(\% \mathrm{~b} / \mathrm{b})$ \\
\hline 1. & K0 & 1,18 \\
2. & K1 & 1,07 \\
3. & K2 & 1,05 \\
4. & K3 & 1,03 \\
5. & K4 & 1,01 \\
\hline
\end{tabular}

Kadar kafein kopi bubuk Arabika hasil fermentasi sesuai dengan persyaratan SNI Kopi Bubuk 01-3542-2004 dengan rentang yaitu $0,9-2 \%$. Semakin tinggi penambahan konsentrasi $S$. cerevisiae maka kadar kafein akan semakin turun. Hal ini terjadi karena mucilage yang telah hilang akan memudahkan enzim proteolitik yang berasal dari $S$. cerevisiae untuk masuk ke dalam sitoplasma dan menguraikan kafein pada biji kopi (Ikrawan et al., 2012).

\section{KESIMPULAN}

Berdasarkan hasil penelitian yang telah dibandingkan dengan SNI Syarat Karakteristik Kopi Bubuk Arabika hasil fermentasi menggunakan $S$. cerevisiae dengan konsentrasi $0 \%, 1 \%, 2 \%, 3 \%$ dan $4 \%$ sesuai dengan syarat karakteristik kopi berdasarkan SNI Kopi Bubuk 01-3542-2004 dengan nilai kadar air 2,33-1,68\% b/b, sari kopi 30,74-30,35\% b/b dan kadar kafein $1,18-1,01 \%$ b/b. Pada proses fermentasi terjadi penurunan nilai $\mathrm{pH}$ fermentasi dan gula pereduksi serta terbentuknya etanol. 


\section{DAFTAR PUSTAKA}

Association of Official Analytical Chemist . 2005. Official Method of Analysis of AOAC International. Edisi ke-18. AOAC International. Maryland.

Avallone, S., J. M. Brillouet, B. Guyot, E. Olguin, dan J. P. Guiraud. 2002. Involvement of Pectolytic Microorganism in Coffee Fermentation. International Journal of Food Science and Technology 37: 191-198.

Butt, M.S., A.M.T. Sultan, A. Imran, M. Yasin dan M. Imran. Evaluating the effect of decaffeination on nutritional and antioxidant status of different coffee brands. 2011. Internet J Food Saf. 13: 198-207.

Board, R. G. 1983. A Modern Introduction to Food Microbiology 1st ed.,: 1-50. Blackwell Scientific Publications. United States.

Clarke, R.J. dan R. Macrae. 1987. Coffee Volume 1 Coffee Chemistry. Elsevier Applied Science. London and New York.

Daud, M., Safii, W., dan Syamsu, K. 2012. Biokonversi bahan berlignoselulosa menjadi bioetanol menggunakan Aspergillus niger dan Saccharomyces cerevisiae. Jurnal Perennial 8 (2): 43-51.

Farah, A. 2012. Coffe: Emerging Health Effects and Disease Prevention. Blackwell. Amazon.

Fitri, N.S. 2009. Pengaruh Berat dan Waktu Penyeduhan Terhadap Kadar Kafein dari Bubuk Teh. Skripsi. Fakultas Matematika dan Ilmu Pengetahuan Alam. Universitas Sumatera Utara. Medan.

Gadd, G dan V. Karamuchka. 1998. Interaction of Saccharomyces cerevisiae with Gold : Toxicity and Accumulation. Bio Metals 12: 289-294.

Gunalan, G, N. Myla, dan R. Balabhaskar. 2012. In Vitro Antioxidant Analysis of
Selected Coffee Bean Varieties. Journal of Chemical and Pharmaceutical Research. 4 (4): 2126-2132.

Harborne, J.B. 1987. Metode Fitokimia Penuntun Cara Modern Menganalisis Tumbuhan. Diterjemahkan oleh Kosasih Padmawinata dan Iwan Sudiro. ITB. Bandung.

Hoffmann, J. 2014. The World Atlas of Coffee: From Beans to Brewing Coffees Explored, Explained and Enjoyed. Firefly Books. North America.

Ikrawan, Y., Hervelly, dan M.M. Panuntas. 2012. Kajian Konsentrasi Koji Saccharomyces cerevisiae var. Ellipsoideus dan Suhu Pada Proses Fermentasi Kering Terhadap Karakteristik Kopi Var. Skripsi. Universitas Pasundan. Bandung.

Ling 1. S, N. I. N. Daud, dan O. Hassan. 2000. Determination Of Coffee Content In Coffee Mixtures. Malaysian Journal of Analytical Sciences. Vol. 7(2): 327-332.

Maria, I.L.T. 2009. Pengendalian Fermentasi dengan Pengaturan Konsentrasi Ragi dan Lama Fermentasi Terhadap Karakteristik Kopi Instan Secara Mikroenkapsulasi. Skripsi. Universitas Sumatera Utara.Medan.

Mushlihah, S. dan Herumurti, W. 2010. Pengaruh $\mathrm{pH}$ dan Konsentrasi Zymonas Mobilis Untuk Produksi Etanol dari Sampah Buah Jeruk. Jurusan Teknik Lingkungan. Fakultas Teknik Sipil dan Perencanaan.Institut Teknologi Sepuluh November. Surabaya.

Najiyati, S dan Danarti. 2001. Kopi Budidaya dan Penanganan Lepas Panen. Penebar Swadaya. Jakarta.

Nopitasari, I. 2010. Proses Pengolahan Kopi Bubuk (Campuran Arabika dan Robusta) Serta Perubahan Karakteristiknya Selama Penyimpanan. Skripsi. Fakultas Teknologi Pertanian. Institut Pertanian Bogor. Bogor. 
Panggabean, E. 2011. Buku Pintar Kopi. Agro Media Pustaka. Jakarta.

Pastiniasih, I. 2012. Pengolahan Kopi Instan Berbahan Baku Kopi Lokal Buleleng, Bali (Campuran Robusta Dan Arabika). Skripsi. Fakultas Teknologi Pertanian. Institut Pertanian Bogor. Bogor.

Rahim, D. A. 2009. Produksi Etanol oleh Saccharomyces cerevisiae var. ellipsoideus dari Sirup Dekstrin Pati Sagu (Metroxylon sp.) Menggunakan Metode Aerasi Penuh dan Aerasi Dihentikan. Skripsi. Fakultas Teknologi Pertanian. Institut Pertanian Bogor. Bogor.

Ramadhan, A. dan H. Phaza. 2010. Pengaruh Konsentrasi Etanol, Suhu, dan Jumlah Stage Pada Ekstraksi Oleoresin (Zingiber officinale Rosc) Secara Batch. Skripsi. Universitas Diponegoro. Semarang.

Ridwansyah. 2003. Pengolahan Kopi. Fakultas Pertanian Universitas Sumatera Utara. Medan.

Robinson, T. 1995. Kandungan senyawa organik tumbuhan tinggi. Diterjemahkan oleh prof. Dr. Kosasih padnawinata. ITB. Bandung.

Rusdi. 1990. Tetumbuhan Sebagai Sumber Bahan Obat. Pusat Penelitian Universitas Andalas. Padang.

Ahuja. S, and N. Jespersen. 2006. Comprehensive Analytical Chemistry. Vol 47. Elsevier.

Sabrina, K., S. Wonorahardjo, dan N. Zakia. 2012. Perbandingan Metode Spektrofotometri UV-Vis dan Kromatografi Cair Kinerja Tinggi (KCKT) pada Analisis Kadar Asam Benzoat dan Kafein dalam Teh Kemasan. Jurnal UNM. Malang.

Sivetz, M. 1985. How Acidity Affects Coffee Flavour. Di dalam Botany, Biochemistry and Production of Beans and Beverage. The AVI Publishing Company, Inc., Westport, Connecticut.

Standar Nasional Indonesia. 2004. SNI-013542-2004 Kopi Bubuk.

Standar Nasional Indonesia. 1992. SNI-012891-1992 Cara Uji Makanan dan Minuman.

Tejasari., Sulistyowati., Djumarti., R.A.A. Sari. 2010. Karakteristik Gizi Dan Tingkat Kesukaan Minuman Kopi Dekafosin Instan. AGROTEK Vol. 4 (1) : 91-106.

Winarno, F.G. 1992. Kimia Pangan dan Gizi. PT Gramedia Pustaka Utama. Jakarta.

Yeretzian, C., E.C Pascual., dan B.A Goodman. 2012. Effect of roasting condition and grinding on free radical contents of coffee beans stored in air. Food Chemistry. 131: 811-816.

Yusdiali, W. 2008. Pengaruh Suhu dan Lama Penyangraian terhadap Tingkat Kadar Air dan Keasaman Kopi Robusta (Coffea robusta). Disertasi. Universitas Hasanuddin. Makasar.

Sumber Internet:

Bina UKM. 2011. Perkembangan Produksi Kopi Di Indonesia. http://binaukm.com/ 2011/09/perkembangan-produksi-kopidi-indonesia/. Diakses 20 April 2018.

Frank, H. A., dan A. S. D. Cruz. 1996. Bacteria Responsible for Mucilage Layer Decomposition in Kona Coffee Cherries. http://www.aem.asm.org. Diakses 10 April 2018.

Murthy, P., dan M. Naidu. 2011. Improvement of Robusta Coffee Fermentation with Microbial Enzymes. http://www.idosi .org. Diakses 10 April 2018 